\title{
GAYA KEPEMIMPINAN TRANSFORMASIONAL KEPALA SEKOLAH DAN PENGARUHNYA TERHADAP PRESTASI PESERTA DIDIK
}

\author{
Regita Damopolii ${ }^{1}$, Alfian Erwinsyah ${ }^{2}$ \\ ${ }^{1}$ Mahasiswi MPI FITK IAIN Sultan Amai Gorontalo \\ ${ }^{2}$ Institut Agama Islam Negeri Sultan Amai Gorontalo \\ email: regitadamopolii@gmail.com
}

\begin{abstract}
Abstrak
Gaya kepemimpinan merupakan norma perilaku yang di gunakan oleh seseorang pada saat orang tersebut mencoba mempengaruhi perilaku orang lain. Gaya kepemimpinan adalah suatu pola perilaku yang konsisten yang di tunjukkan oleh pemimpin dan di ketahui pihak lain. Ketika pemimpin berusaha mempengaruhi kegiatankegiatan orang lain. Gaya kepemimpinan juga merupakan pola tingkah laku seorang pemimpin dalam proses mengarahkan dan mempengaruhi guru dan siswa. Penelitian ini merupakan penelitian kuantitatif dengan tujuan untuk mengetahui seberapa besar pengaruh gaya kepemimpinan transformasional kepala sekolah terhadap prestasi peserta didik di SMA N 1 Pinolosian. Penelitian ini dilaksanakan di SMA N 1 Pinolosian.

Hasil Penelitian membuktikan bahwa variabel $X$ (gaya kepemimpinan transformasional kepala sekolah) berpengaruh secara signifikan terhadap variabel $Y$ (prestasi peserta didik) di SMA $N 1$ Pinolosian, dengan perbandingan $T_{\text {hitung }}>T_{\text {tabel }}=$ $6.391>0.297$ dan melalui analisis regresi sederhana pada tabel $R$ Square, diketahui Pengaruh variabel $X$ (gaya kepemimpinan transformasional kepala sekolah) terhadap variabel $Y$ (prestasi peserta didik) di SMA $N 1$ Pinolosian sebesar 49.3\% yang berarti terdapat $50.7 \%$ prestasi peserta didik dipengaruhi oleh faktor yang lain.
\end{abstract}

Kata Kunci : Gaya Kepemimpinan Transformasional, Prestasi

\section{PENDAHULUAN}

Kepemimpinan adalah suatu kegitan mempengaruhi orang lain agar orang tersebut mau bekerja sama (mengolaborasi dan mengelaborasi potensinya) untuk mencapai tujuan yang telah di tetapkan. Kepemimpinan juga sering di kenal sebagai kemampuan untuk memperoleh konsensus anggota organisasi untuk melakukan tugas manajemen agar tujuan organisasi tercapai. ${ }^{1}$

Kepala sekolah adalah pengelola pendidikan di sekolah secara keseluruhan. Dalam suatu lingkungan pendidikan,kepala sekolah bertanggung jawab penuh untuk,mengelola dan memberdayakan sumber daya manusia yang ada di sekolah itu. Kepala seekolah juga adalah guru yang mendapat tugas tambahan sebagai kepala sekolah dimana peranannya sangat diperlukan dalam mengkoordinasikan, menggerakkan, dan menyerasikan semua sumber daya pendidikan yang tersedia di lembaganya, selain itu

${ }^{1}$ Abd Wahab \& Umiarso,Kepemimpinan Pendidikan dan Kecerdasan Spiritual,(Jogjakarta: ArRuzz Media,2016),h.89. 
kepala kepala sekolah juga dituntut untuk mempunyai kemampuan manajemen dan kepemimpinan yang memadai agar mampu mengambil inisiatif dan prakarsa untuk meningkatkan kualitas dan mutu pendidikan di lembaga yang dipimpinnya. ${ }^{2}$

Keberhasilan suatu sekolah pada hakekatnya terletak pada efisiensi dan efektivitas penampilan seorang kepala sekolah. Sedangkan sekolah sebagai lembaga pendidikan,bertugas menyelengarakan proses pendidikan dan proses belajar mengajar dalam usaha mencerdaskan kehidupan bangsa. Gaya kepemimpinan pada dasarnya mengandung pengertian sebagai suatu perwujudan tingkah laku dari seorang pemimpin,yang menyangkut kemampuannya dalam memimpin yang dapat mempengaruhi bawahannya. Perwujudan tersebut biasanya membentuk suatu pola atau bentuk tertentu. Penertian gaya kepemimpinan yang demikian ini sesuai dengan pendapat yang di sampaikan oleh E.Mulyasa. E.Mulyasa menyatakan bahwa cara yang di pergunakan pemimpin dalam memengaruhi para pengikutnya tersebut di kenal sebagai gaya kepemimpinan. Dalam konteks pendidikan, seperti yang di katakan oleh Edward Sallis, bahwa gaya kepemimpinan tertentu dapat mengantarkan institusi pada revolusi mutu. ${ }^{3}$

Kepemimpinan transformasional merupakan salah satu diantara sekian model kepemimpianan,yang menurut Tracey dan Hinkim merupakan proses ke arah upaya peningkatan diri baik pemimpin maupun pengikut ke tingkat moralitas dan motivasi yang lebih tinggi. Gaya kepemimpinan transformasional merupakan prosedur pengaruh sadar dalam individu atau kelompok, untuk membuat perubahan terus-menerus,perkembangan dari status quo dan kinerja organisasi secara keseluruhan ${ }^{4}$

Cagne berpendapat bahwa yang dimaksud dengan prestasi belajar adalah tingkat kemampuan actual yang dapatdiukur, baik berupa penguasaan ilmu pengetahuan, sikap maupun keterampilantertentu yang dicapai seseorang sebagai hasil dari apa yang dipelajari seoranganak didik di sekolah. Lebih lanjut dijelaskan bahwa keberhasilan anak didik,adalah gambaran hasil dari proses belajar yang merupakan kristalisasi dari berbagai komponen yang saling terkait dan saling berpengaruh.

Bloom, mengatakan bahwa prestasi belajar merupakan hasil perubahan tingkah la ku yang meliputi kemampuan daya pikir (kognisi), kemampuan perasaan (afeksi) dan keterampilan (psikomotor). Ketiga ranah itu tidak dipisahkan meskipun secara konseptual dapat dibedakan menurut ciri-cirinya.

Dalam teori taksonomi yang dikemukakan Bloom dikatakan, bahwa melalui pros es belajar akan terjadi perubahan kemampuan daya pikir (kognisi) dalam bidang studi yang meliputi enam tingkat, yaitu :

1. Pengetahuan, yaitu dapat mengenal, mengingat dan memproduksi bahan pengetahu an atau pelajaran yang pernah diberikan;

2. Pemahaman, yaitu memahami materi atau gagasan yang diberikan. Mahasiswamengetahui apa yang disampaikan dan dapat menggunakan materi ataug

2 Sidik, Firman. "KONSEP PENGEMBANGAN KURIKULUM PENDIDIKAN ISLAM." (2016): 100-114.

${ }^{3}$ Abd Wahab \& Umiarso,h.92 2014),h.65

${ }^{4}$ Agus Wibowo,Manager \& Leader Sekolah Masa Depan, (Yogyakarta : Pustaka Pelajar, 
agasan yang diberikan tanpa perlu menghubungkannya dengan materi lainatau melihat implikasinya;

3. Penerapan, yaitu menggunakan hal-hal yang abstrak dalam situasi yangkhusus dan konkrit;

4. Analisis, yaitu menguraikan suatu materi atau bahan yang diberikan, menjadi unsur-unsur atau bagian-bagian, sehingga kedudukan atau hubungan antar unsur atau bagian yang diungkapkan menjadi jelas;

5. Sintesis, yaitu menghimpun atau menyusun unsur-unsur atau bagianbagiansehingga membentuk keseluruhan, proses bekerja dengan bahan-bahan, unsur-unsur, dan menyusun atau menggabungkannya menjadi pola atau struktur tertentu;

6. Evaluasi, yaitu memberikan pertimbangan mengenai nilai dari bahan-bahandan metode-metode untuk tujuan tertentu.

Dengan demikian,dapat disimpulkan bahwa belajar adalah proses perubahan perilaku yang ditandai dengan adanya perubahan pada kognisi, afeksi maupun psikomotorik yang relatif menetap.

Sedangkan prestasi belajar adalah hasil belajar yang dapat diukur baik intelektual, pengetahuan, sikap maupun keterampilannya. ${ }^{5}$

Adapun perilaku-perilaku baik yang dapat di lihat pada kepala sekolah SMA Negeri 1 Pinolosian yaitu : Disiplin waktu, ramah, jujur, adil, motivator yang baik, Relijius dan masih banyak perilaku terpuji lainnya. Sedangkan prestasi peserta didik tersebut hanya tergantung dari tiap-tiap peserta didik. Setiap anak didik berbeda-beda sesuai dengan karakter masing-masing, sehingganya ada siswa yang baik dan ada juga yang buruk prestasinya. Jadi tinggal tergantung dari bagaimana kepala sekolah mendorong guru-guru yang ada di sekolah tersebut agar bisa mendidik anak-anak di sekolah tersebut sesuai dengan tujuan sekolah. Berdasarkan latar belakang masalah di atas dapat di identifikasikan beberapa permasalahan sebagai berikut :

1. Kepala sekolah belum maksimal dalam mengelola kinerja sekolah sehingga prestasi peserta didik yang di hasilkan kurang baik.

2. Pengawasan kepala sekolah belum terlalu ketat terhadap kineja warga sekolah dalam pencapian prestasi peserta didik agar lebih baik.

3. Minimnya penghargaan yang di berikan kepala sekolah kepada guru-guru yang baik dan murid yang berprestasi.

Berdasarkan uraian latar belakang di atas dan agar masalah yang di teliti dapat di petakan secara sistematis,maka berikut ini penulis merumuskan masalah sebagai berikut :

1. Apakah gaya kepemimpinan transformasional kepala sekolah berpengaruh secara signifikan terhadap prestasi peserta didik di SMA N 1 Pinolosian?

2. Berapa besar pengaruh gaya kepemimpinan transformasional kepala sekolah terhadap prestasi peserta didik di SMA N 1 Pinolosian?

${ }^{5}$ https://www.scribd.com/doc/147761893/Prestasi-Belajar-Kebiasaan-Belajar-Dan-MotifBerprestasi,di akses tanggal 01 oktober 2018, jam 11.44 wita. 


\section{KEPEMIMPINAN TRANSFORMASIONAL}

Transformasional berarti perubahan besar dan menyeluruh, bukan sekedar perubahan secara alami (Change). Kepala sekolah transformasional adalah kepala sekolah yang memiliki ambisi besar untuk melakukan perubahan-perubahan di sekolah agar di peroleh tingkat produktifitas sekolah yang lebih tinggi. Kepala sekolah transformasional adalah kepala sekolah yang visioner dan futuristik, yaitu memiliki wawasan jauh ke depan. ${ }^{6}$

Istilah kepemimpinan transformasional (transformational leadership) adalah proses mempengaruhi secara transformasional, yang memiliki ciri dominan, yaitu :

a. Memiliki sensitifitas pengembangan organisasi.

b. Mengembangkan visi bersama antarkomunitas organisasi.

c. Mendistribusikan peran kepemimpinan.

d. Mengembangkan kultur sekolah.

e. Melakukan usaha-usaha restrukturisasi di sekolah.

Kepemimpinan transformasional merefleksikan transendensi kepentingan, baik pemimpin maupun pengikut. Kepala seolah harus memberikan motif bagi para pengikutnya untuk meraih tujuan-tujaun pemimpin dan pengikut secara lebih efektif. Kepemimpina yang efektif transformsional berkenaan dengan bagaimana cara menginspirasi dan memenangkan komitmen para pengikutnya. ${ }^{7}$

Ada hal yang harus dilakukan oleh kepala sekolah yang tranformasional antara lain : mentapkan arah, mencakup membangun visi bersama, menciptakan konsensus tentang tujuan-tujuan dan prioritas-prioritas, serta membangun ekspektasi performa yang tinggi. Mengembangkan sumber daya manusia : mecakup menyedikan dukungan individual, menawarkan stimulus intelektual dan memberikan contoh nilai-nilai dan praktik-praktik yang penting. Mendesain ulang organisasi : meliputi membangu suatu struktur yang kolaboratif, menciptakan struktur-struktur dan proses-proses pengambilan keputusan bersama, serta membangun hubungan dengan para orang tua dan komunitas yang lebih besar. ${ }^{8}$

Kepemimpinan transformasional seringkali di persandingkan dengan kepemimpinan transaksional, karena setiap perilaku kepemimpinan melahirkan transaksi antara pemimpin dan yang di pimpin.Kepemimpinan transormasional merupakan gaya kepemimpinan yang menutamakan pemberian kesempatan atau mendorong semua unsur yang ad di sekolah untuk bekerja atas dasar sistem nilai yang luhur, sehingga semua unsur yang ada di sekolah (guru, siswa, staf pengajar dan staf lainnya, orang tua siswa, masyarakat dan sebagainya) bersedia tanpa paksaan, berpartisipasi secara optimal dalam rangka mencapai tujuan sekolah.

Menurut luthans ada ciri-ciri dominan seorang yang telah berhasil menerapkan gaya kepemimpinan transformasional. Ciri-ciri yang di maksud adalah sebagai berikut :

a. Mengidentifikasi dirinya sebagai agen pembaharuan,

b. Memiliki sifat pemberani

70.

${ }^{6}$ Agus Wibowo, Manager \& Leader Sekolah Masa Depan,(Yogyakarta : Pustaka Pelajar, 2014), h.

${ }^{7}$ Raihani , kepemimpinan sekolah transformatif, ( Yogyakarta : LKIS, 2010), h. 32

${ }^{8}$ Raihani, kepemimpinan sekolah transformatif, h.33 
c. Mempercayai orang lain

d. Bertindak atas dasar sistem nilai (bukan atas dasar kepentingan individu, atas dasar kepentingan dan desakan kroninya).

e. Meningkatkan kemampuan secara terus menerus. ${ }^{9}$

1. Karakteristik Kepemimpinan Transformasional

Pemimpin Transformasional menurut Conger, Bennis dan Nunus, merupakan pemimpin yang mampu mengantarkan anak buahnya menuju suatu kesadaran diri yang tinggi dan dinamis. Sementara menurut Bass dan silin kepemimpinan transformasional ini memiliki tiga ciri khas, yaitu : ${ }^{10}$

a. Memiliki kharisma yang menyebabkan selalu di cintai oleh anak buahnya. Dengan kharisma yang di miliki pemimpin transformasional mampu menumbuhkan rasa percaya diri dan rasa saling mempercayai dalam diri bawahannya. Pemimpin transformasional juga mampu menciptakan antusiasme anak buah, mampu membedahkan hal-hal yang benar-benar penting, dan membangkitkan kecintaan pada organisasi. Melalui kharismanya, pemimpin mampu mengilhami loyalitas dan ketekunan, menanamkan kebanggaan dan kesetiaan, serta membangkitkan rasa hormat anak buah pada dirinya.

b. Konsideran individual. Pemimpin transformasional akan memperhatikan faktorfaktor kekhasan serta keunikan individual bawahannya. Oleh karena itu, ia tidak akan menganggap anak buahnya secara sama rata. Karena adanya perbedaan tersebut, maka pelayanan dan pengembangannya pun berbeda-beda satu dengan yang lainnya.

c. Stimulasi intelektual. Pemimpin transformasional selalu akan melakukan stimulasistimulasi intelektual. Hal ini dapat di lihat dalam kemempuannya menciptakan, menginteprestasikan, dan mengelaborasi simbol-simbol yang muncul dalam kehidupan, serta menajak bawahan untuk berfikir dengan cara-cara baru. Pendeknya, bawahan di kondisikan pada situasi untuk slalu bertanya pada diri sendiri dan membandingkannya dengan asumsi yang berkembang di masyarakat. Hasil refleksi ini selanjutkan di gunakan untuk mengembangkan kemampuan serta pemecahan maslah secara bebas.

Fullal dan Leithwood, bahkan dengan tegas merekomendasikan kepemimpinan transformasional sebagai kepemimpianan pendidikan yang di butuhkan di masa depan. Tipe kepemimpinan transformasional ini tidak hanya mampu meningkatkan komitmen staf Hunt, mengkomunikasikan suatu visi dan implementasinya Dunphy, \& Stace, tetapi juga mampu memberikan kepuasan dalam bekerja dan mengembangkan fokus yang berorientasi pada klien Shaskin and Kiser.

\section{Prinsip-prinsip Kepemimpinan Transformasional}

Menurut teori kepemimpinan transformasional, untuk menjadi pemimpin yang sukses, kepala sekolah harus membangkitkan komitmen pengikutnya (dalam hal ini semua warga sekolah) untuk membangun nilai-nilai organisasi sekolah dengan kesadaran sendiri, mengembangkan visi sekolah, melakukan perubahan-perubahan, dan mencari

\footnotetext{
${ }^{9}$ Agus Wibowo, Manager \& Leader Sekolah Masa Depan, h. 68

${ }^{10}$ Ibid, h. 66
} 
terobosan-terobosan baru untuk meningkatkan produktivitas sekolah. Untuk menjadi pemimpin transformasional, seorang kepala sekolah menurut Wuradji harus melaksanakan tugasnya melalui dua cara : ${ }^{11}$

a. Membangun kesadaran segenap warga sekolah akan pentingnya semua pihak mengembangkan nilai-nilai kerja keras dalam upaya meningkatkan produktivitas sekolah, dan

b. Mengembangkan tanggung jawab dan kesadaran berorganisasi dengan mengembangkan kesadaran ikut memiliki sekolah (sense of belonging), dan kesadaran bertanggung jawab menjaga keutuhan sekolah, serta berusaha memajukan sekolah (sense of responsibility).

Kepala sekolah Transformasional sebagaimana di uraikan akan tampil sebagai seorang pemandu atau pengarah yang baik ; apa yang di perintahkan akan di lakukan oleh anak buahnya, sementara larangannya akan di patuhi. Guru, karyawan, peserta didik dan seluruh warga sekolah, akan menaruh hormat, segan dan simpati terhadap kepala sekolah model demikian. Mereka dengan senang hati akan bersama-sama dengan kepala sekolah, menggapai tujuan pendidikan karakter pada khususnya, dan tujuan sekolah pada umumnya.

Kepala sekolah transformasional bukan sekedar individu yang hanya memiliki tanggung jawab atas beberapa pengikut, tetapi merupakan individu dalam komunitas bertindak. Maka, tindakan kepala sekolah merupakan yang paling fundamental dan menentukan eksistensinya sebagai pemimpin. Tindakan kepala sekolah transformasional atau istilah "kerennya" berkarakter, akan menyebabkan tindakan para guru berkarakter, staf administrasi berkarakter, peserta didik berkarakter, dan seluruh warga sekolah yang berkarakter.

Kepala sekolah yang memiliki kepemimpinan partisipasif-transformasional memiliki kecenderungan untuk menghargai ide-ide baru, cara baru, praktik-praktik baru dalam proses belajar-mengajar di sekolahnya, dan dengan demikian sangat senang jika guru melaksanakan classroom action research. Sebab, dengan penelitian kelas itu sebenarnya guru akan mampu menutup gap antara wacana konseptual dan realitas dunia praktik profesional. Akibat positifnya ialah dapat di temukannya solusi dari persoalan keseharian yang di hadapi guru akan mampu memecahkan sendiri persoalan yang muncul dari praktik persoalannya, dan oleh karena itu mereka dapat selalu meningkatkannya secara berkelanjutan. ${ }^{12}$

\section{PRESTASI BELAJAR}

Prestasi belajar adalah perubahan perilaku individu. Individu akan memperoleh perilaku yang baru, menetap, fungsional, positif, di sadari dan sebagainya. Perubahan perilaku sebagai hasil pembelajaran atau prestasi belajar ialah perilaku secara keseluruhan yang mencakup aspek kognitif, efektif, konatif, motorik, ( Mohammad Surya,). Purwanto menyatakan bahwa prestasi belajar adalah perubahan perilaku yang terjadi setelah mengikuti proses belajar mengajar sesuai dengan tujuan pendidikan. R.M Gagne (Mohammad Surya) menyatakan bahwa prestasi belajar adalah kecakapan intelektual

\footnotetext{
${ }^{11}$ Agus Wibowo, Manager \& Leader Sekolah Masa Depan, h. 73

${ }^{12}$ Agus Wibowo, Manager \& Leader Sekolah Masa Depan, h. 77
} 
(diskriminasi, konsep konkrit, konsep abstrak, aturan dan aturan lebih tinggi), strategi kognitif, sikap dan kecakapan motorik.

Berdasarkan pengertian tersebut, dapat di simpulkan bahwa prestasi belajar merupakan kemampuan yang meliputi segenap ranah psikologi (kognitif, efektif, dan psikomotor) yang berubah sebagai akibat pengalaman dan proses belajar peserta didik. Prestasi belajar akan terlihat berdasarkan perubahan perilaku sebelum dan sesudah belajar peserta didik. Hal tersebut pada dasarnya dapat di jadikan sebagai tolak ukur berhasil atau tidaknya suatu kegiatan belajar mengajar.

Pada dasarnya indikator prestasi belajar di tunjukkan dengan adanya perubahan tingkah laku yang mencakup ranah kognitif, afektif dan psikomotor. Muhibbin Syah menyatakan bahwa prestasi belajar idealnya meliputi segenap ranah psikologi yang berubah sebagai akibat pengalaman dan proses belajar peserta didik. Mengukur prestasi belajar kita harus mengetahui garis-garis besar indikator (petunjuk adanya prestasi tertentu) di kaitkan dengan jenis prestasi yang hendak di ungkapkan atau di ukur. ${ }^{13}$

Seseorang melakukan proses belajar karena memiliki tujuan untuk mendapatkan suatu prestasi, dan proses itu tidak semudah yang dibayangkan, karena untuk mencapai prestasi yang gemilang memerlukan perjuangan dan pengorbanan dengan berbagai tantangan yang harus dihadapi. Menurut Kamus Besar Bahasa Indonesia prestasi adalah: "Penguasaan pengetahuan atau ketrampilan yang dikembangkan kemudian ditunjukkan dengan nilai tes atau angka yang diberikan oleh pengajar". Prestasi belajar merupakan cerminan dari tingkatan yang mampu dicapai oleh mahasiswa dalam meraih tujuan yang sudah ditetapkan disetiap bidang studi. Dari beberapa definisi di atas, dapat kesimpulan bahwa prestasi belajar merupakan hasil usaha belajar yang dicapai mahasiswa ditunjukkan dengan nilai tes atau angka yang diberikan oleh pengajar.

\section{Faktor- Faktor Yang Mempengaruhi Prestasi Belajar}

Berhasil tidaknya peserta didik dalam belajar di sebabkan oleh beberapa faktor yang mempengaruhi pencapaian prestasi belajar, yaitu berasal dari dalam diri peserta didik yang belajar dan ada pula dari luar dirinya. Dalyanto menyatakan bahwa faktorfaktor yang mempengaruhi prestasi belajar adalah faktor internal ( kesehatan, intelegensi, dan bakat,minat motivasi dan cara belajar) dan faktor eksternal (sekolah,keluarga, masyarakat dan lingkungan sekitar). Sedangkan Muhibin Syah mengatakan bahwa prestasi belajar dapat dipengaruhi oleh faktor internal (keadaan/kondisi jasmani, rohani peserta didik) dan faktor eksternal (kondisi lingkungan di sekitar peserta didik) dan faktor pendekatan belajar (approach to learning). ${ }^{14}$

Menurut Slameto, faktor-faktor yang mempengaruhi prestasi belajar dapat digolongkan menjadi 2, yaitu "faktor intern faktor ekstern" :

1. Faktor intern:

a.) Faktor jasmani, yaitu faktor kesehatan dan cacat tubuh.

b.) Faktor psikologis, yaitu inteligensi, perhatian, minat, bakat, motif, kematangan dan kesiapan.

\footnotetext{
${ }^{13}$ Euis Karwati \& Donni Juni Priansa, Manajemen Kelas,(Bandung : Alfabeta,2015),h.155

${ }^{14} \mathrm{Ibid}, \mathrm{h} .156$
} 
c.) Faktor kelelahan, yaitu kelelahan jasmani yang terlihat dengan lemahnya kondisi tubuh dan timbul kecenderungan untuk membaringan tubuh, sedangkan kelelahan rohani dapat dilihat dengan adanya kelesuan dan kebosanan, sehingga minat dan dorongan akan berkurang.

2. Faktor ekstern:

a.) Faktor keluarga, meliputi cara orang tua mendidik, relasi antara anggota keluarga, suasana rumah, keadaan ekonomi keluarga, pengertian orang tua dan latar belakang kebudayaan.

b.) Faktor sekolah, meliputi metode mengajar, kurikulum, relasi guru dengan siswa, relasi siswa dengan siswa, disiplin sekolah, alat pelajaran, waktu sekolah, keadaan gedung, metode belajar, dan tugas rumah.

c.) Faktor masyarakat, meliputi kegiatan siswa dalam masyarakat, mass media, teman bergaul, dan bentuk kehidupan masyarakat.

Menurut Muhibbin Syah dalam psikologi belajar, mengelompokkan faktor-faktor yang mempengaruhi belajar menjadi tiga macam, yaitu:

1. Faktor internal Faktor ini berasal dari dalam diri mahasiswa sendiri yang meliputi faktor fisiologis (yang bersifat jasmani) dan aspek psikologis (yang bersifat rohani).

a.) Aspek fisiologis Kondisi umum jasmani seseorang yang menandai tingkat kesehatan organ-organ tubuh dan sendisendinya dapat mempengaruhi semangat dan intensitas mahasiswa dalam mengikuti kegiatan pembelajaran, hal ini dikarenakan kesehatan organ tubuh, khususnya organ indera pendengar dan penglihatan akan sangat mempengaruhi kemampuan mahasiswa dalam menyerap informasi dan pengetahuan dalam kegiatan pembelajaran. Jika kondisi kesehatan sendiri kurang sehat, maka mahasiswa tersebut tidak akan dapat berkonsentrasi dikarenakan perhatiannya beralih pada ketidaknyamanan tubuh yang dirasakan.

b.) Aspek psikologis. Banyak faktor yang termasuk dalam aspek psikologis diantaranya faktor rohaniah yang dianggap lebih penting. Faktor-faktor ini seperti: tingkat kecerdasan, sikap, bakat, minat dan motivasi.

2. Faktor eksternal Faktor eksternal terdapat dua macam yaitu:

a.) Lingkungan sosial Lingkunagan sosial mencakup lingkungan sekolah, masyarakat dan lingkungan keluarga.

b.) Lingkungan nonsosial Faktor yang termasuk lingkungan nonsosial yaitu gedung sekolah dan letaknya, rumah tempat tinggal keluarga dan letaknya, alat-alat belajar, keadaan cuaca, dan waktu belajar yang digunakan dalam belajar.

3. Faktor pendekatan belajar Faktor pendekatan belajar merupakan upaya belajar yang meliputi strategi dan metode yang digunakan mahasiswa untuk melakukan kegiatan mempelajari materi pelajaran. 


\section{METODOLOGI}

Jenis penenelitian ini adalah penelitian kuantitatif lapangan (field research). Penelitian kuantitatif menekankan analisisnya pada data-data numerical (angka) yang diolah dengan metode statistika. ${ }^{15}$ Sedangkan penelitian lapangan adalah penelitian yang menggunakan kehidupan nyata sebagai tempat kajian. ${ }^{16}$ Penelitian ini menggunakan rumus korelasi, yaitu penelitian yang melibatkan hubungan satu atau lebih variabel dengan satu atau lebih variabel lain. Bentuk hubungan dalam penelitian ini adalah Bivaret, yaitu hubungan yang melibatkan satu variabel bebas dengan satu variabel terikat. ${ }^{17}$

Pendekatan penelitan yang digunakan dalam penelitian ini ialah penelitian survei cross sectional, yaitu konsep Penelitian yang mempelajari dinamika korelasi antara faktor-faktor resiko dengan efek, dengan cara pendekatan observasi atau pengumpulan data sekaligus pada suatu saat (point time approach). Artinya, tiap subjek penelitian hanya diobservasi sekali saja dan pengukuran dilakukan terhadap status karakter atau variabel subjek pada saat pemeriksaan. Melalui penelitian ini pula, seorang peneliti hanya mengobservasi fenomena pada satu titik waktu tertentu untuk menjelaskan hubungan satu variabel dengan variabel lain pada populasi yang diteliti, menguji keberlakuan suatu model atau rumusan hipotesis serta tingkat perbedaan diantara kelompok sampling pada satu titik waktu tertentu. ${ }^{18}$

1) Populasi

Menurut Sugiono, populasi adalah wilayah generalisasi yang terdiri atas: obyek/subyek yang mempunyai kualitas dan karasteristik tertentu yang ditetapkan peneliti untuk di pelajari dan kemudian di tarik kesimpulannya. ${ }^{19}$

Populasi dalam penelitian ini meliputi seluruh guru yang berada di SMA N 1 Pinolosian yang berjumlah 44 orang. Dan Peserta didiknya 303 Orang dari Kelas X XII.

2) Sampel

Sampel penelitian adalah suatu himpunan bagian dari populasi yang anggotanya disebut sebagai subjek. Menurut Tulus Winarsunu, sebagian kecil individu yang dijadikan wakil dalam penelitian disebut sampel. ${ }^{20}$ Menurut Suharsini Arikunto ada beberapa rumus yang dapat di gunakan peneliti untuk menentukan jumlah sampel. Jika peneliti mempunyai beberapa ratus subjek dalam populasi,maka peneliti dapat menentukan kurang lebih $25 \%$ - 30\% dari jumlah subjek tertentu. ${ }^{21}$

\footnotetext{
${ }^{15}$ Suranto, Metodologi Penelitian dalam Pendidikan dengan Program SPSS, (Semarang: CV. Ghiyyas Putra, 2009), h. 25.

${ }^{16}$ Purwanto, Metodologi Penelitian Kuantitatif Untuk Psikologi dan Pendidikan, (Yogyakarta: Pustaka Pelajar, 2010), h. 167.

${ }^{17}$ Purwanto, Metodologi Penelitian Kuantitatif Untuk Psikologi dan Pendidikan, h. 177.

${ }^{18} \mathrm{http} / / /$ stikaavicenna4.blogspot.co.id/2012/08/makalah-penelitian-crosssectional.html diakses pada tanggal 20 Agustus 2018.

${ }^{19}$ Sugiyono,Metode Penelitian,(bandung : alfabeta,2015),h. 297 2006), h. 11 .

${ }^{20}$ Tulus Winarsunu, Statistik Dalam Penelitian Psikologi dan Pendidikan, (Malang: UMM Press,

${ }^{21}$ Suharsimi Arikunto, Manajemen Penelitian (Jakarta : Rineka Cipta, 2009) h.95
} 
Selanjutnya untuk menentukan ukuran sampel dari jumlah populasi 303 peserta didik peneliti menggunakan $25 \%$ dari 303 populasi yaitu 75 responden. Berikut adalah cara untuk menentukan jumlah sampel di setiap kelas, kelas $\mathrm{X}=131, \mathrm{XI}=80, \mathrm{XII}=92$ yaitu :

$$
\begin{aligned}
& \mathrm{X}=131 / 303 \times 75=32 \\
& \mathrm{XI}=80 / 303 \times 75=19,80 \text { di bulatkan } 20 \\
& \mathrm{XII}=92 / 303 \times 75=22,77 \text { di bulatkan } 23 \\
& \text { Jumlah } \quad=75
\end{aligned}
$$

Menurut Sugiono tehnik yang dapat di gunakan bila populasi mempunyai anggota/unsur yang tidak homogen dan berstrata secara proporsional yaitu tehnik (Proportionate Stratifted Random Sampling). ${ }^{22}$

Adapun teknik pengumpulan data dalam penelitian ini adalah sebagai berikut:

1) Observasi

2) Metode Angket (Kuosioner)

\section{HASIL}

\section{Uji Validitas}

Uji validitas instrumen merupakan suatu ukuran yang menunjukkan tingkat keandalan dan kesahihan suatu alat ukur. ${ }^{23}$ Dalam pengujian instrumen pada penelitian ini, penulis menguji cobakan pada 44 responden. Berdasarkan hasil perhitungan mengunakan program SPSS 16.00 diperoleh hasil uji validitas terhadap 27 butir item pernyataan variabel X (Gaya Kepemimpinan Transformasional Kepala Sekolah) dengan menggunakan taraf nyata/taraf keberartian $\alpha=0.05$ dan $\mathrm{N}=44$ (44 jumlah responden di SMA N 1 Pinolosian), serta dengan kriteria interval kepercayaan 95\%, maka harga $r_{\text {tabel }}=$ 0.297. Untuk menentukan butir instrument yang valid dilakukan uji coba terhadap semua item pernyataan dengan kriteria $r_{\text {hitung }}>r_{\text {tabel }}$. Ini berarti semua item pernyataan dalam angket dikatakan valid jika hasil perhitungan $r_{\text {hitung }}>r_{\text {tabel }}$.

Berdasarkan hasil uji coba instrumen penelitian dari 27 item pernyataan, semuanya valid, Hal ini dikarenakan $r_{\text {hitung }}$ dari item pernyataan di atas lebih besar dari $\mathrm{r}_{\text {tabel. }}$

Selanjutnya untuk variabel Y (Prestasi Peserta Didik) juga dilakukan perhitungan uji validitas terhadap 28 butir item pernyataan variabel $\mathrm{Y}$ dengan menggunakan taraf nyata $\alpha=0.05, \mathrm{~N}=75$, serta dengan kriteria interval kepercayaan $5 \%$.

Berdasarkan hasil uji coba instrumen penelitian dari 28 item pernyataan, semuanya valid, Hal ini dikarenakan $r_{\text {hitung }}$ dari item pernyataan di atas lebih besar dari $r_{\text {tabel. }}$

\footnotetext{
${ }^{22}$ Sugiono, Metode Penelitian Manajeme, (Bandung, Alfabeta, 2014), h. 152

${ }^{23}$ Riduwan, Metode dan Teknik Menyusun Tesis (Cet.VII, Bandung: Alfabeta, 2010) h.109.
} 


\section{Uji Reliabilitas}

Hasil Uji Reliabilitas dilakukan dengan menggunakan SPSS 16.0 dengan menggunakan rumus Alpha Crombach. Berdasarkan hasil perhitungan uji reliabilitas di peroleh nilai r sebagai berikut :

\begin{tabular}{|} 
Reliability Statistics \\
\begin{tabular}{|r|r|}
\hline $\begin{array}{c}\text { Cronbach's } \\
\text { Alpha }\end{array}$ & N of Items \\
\hline .742 & 28 \\
\hline
\end{tabular}
\end{tabular}

Merujuk dari hasil table out put tentang reliability statistics didapat koefisien alpha crombach untuk variabel X (Gaya kepemimpinan transformasional kepala sekolah) yaitu sebesar 0.742. Hasil ini menunjukkan bahwa instrument variabel $\mathrm{X}$ reliable karena $0.742>0.6$.

\section{Reliability Statistics}

\begin{tabular}{|r|r|}
\hline $\begin{array}{c}\text { Cronbach's } \\
\text { Alpha }\end{array}$ & N of Items \\
\hline .742 & 29 \\
\hline
\end{tabular}

Merujuk dari hasil table out put tentang reliability statistics didapat koefisien alpha cronbach yaitu sebesar 0.742 . Hasil ini menunjukkan bahwa instrument variabel Y (prestasi peserta didik) reliabel karena $0.742>0.6$.

\section{Uji Normalitas}

Tests of Normality

\begin{tabular}{|l|r|r|r|r|r|r|}
\hline & \multicolumn{3}{|c|}{ Kolmogorov-Smirnov $^{\mathrm{a}}$} & \multicolumn{3}{c|}{ Shapiro-Wilk } \\
\cline { 2 - 7 } & Statistic & \multicolumn{1}{c|}{ Df } & \multicolumn{1}{c|}{ Sig. } & Statistic & \multicolumn{1}{c|}{$\mathrm{df}$} & \multicolumn{1}{c|}{ Sig. } \\
\hline $\mathrm{X}$ & .126 & 44 & .077 & .947 & 44 & .043 \\
$\mathrm{Y}$ & .132 & 44 & .052 & .940 & 44 & .023 \\
\hline
\end{tabular}

Sumber: Hasil Pengolahan SPSS 16.0

Metode Pengambilan keputusan untuk uji normalitas yaitu jika signifikansi > 0.05 maka data berdistribusi normal dan jika signifikansi $<0.05$ maka data tidak berdistribusi normal.

Berdasarkan hasil pengujian normalitas data mengunakan program SPSS 16.0 didapatkan nilai signifikansi variabel gaya kepemimpinan transformasional kepala sekolah (X) sebesar 0.077, karena nilai Signifikansinya $0.077>0,05$ maka data untuk variabel gaya kepemimpinan transformasional kepala sekolah $(\mathrm{X})$ berdistribusi normal. 
Demikian juga dengan variabel prestasi peserta didik (Y), nilai signifikansinya ialah 0.052> 0,05 Maka data untuk variabel prestasi peserta didik (Y) juga berdistribusi normal.
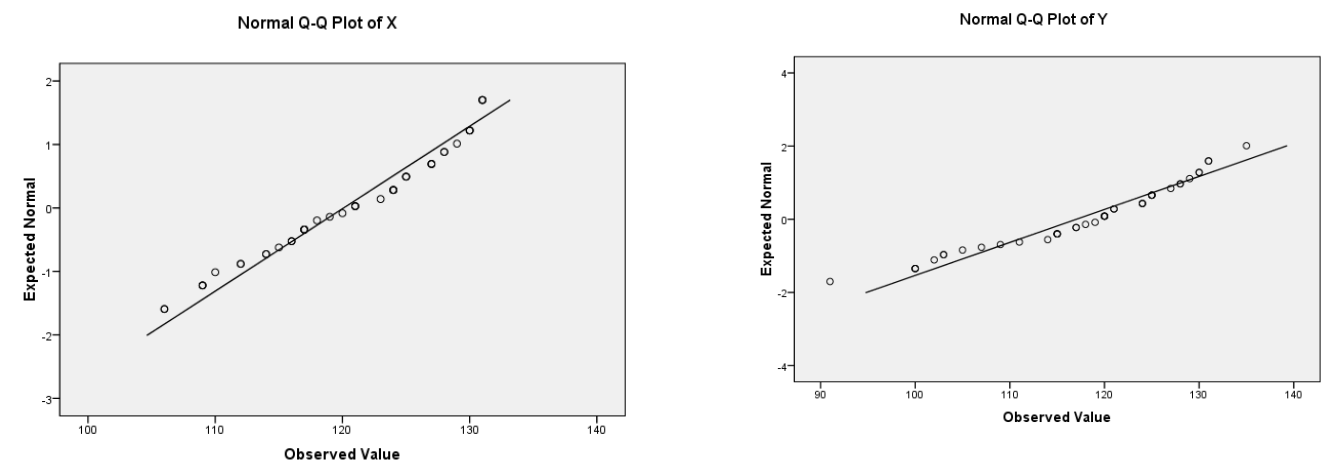

Dari gambar grafik Normal Q-Q Plot juga didapatkan hasil bahwa variabel X dan variabel $\mathrm{Y}$ terlihat sebaran data yang berkumpul disekitar garis uji yang mengarah ke kanan atas, tidak ada data yang terletak jauh dari sebaran data.

Berdasarkan kedua fakta di atas dalam pengujian normalitas data, dapat disimpulkan bahwa data yang digunakan dalam penelitian ini terdistribusi secara normal, sehingga metode analisis yang akan digunakan dalam penelitian ini ialah metode statistic parametrik.

\section{Uji linearitas data}

Pengujian linearitas digunakan sebagai prasyarat dalam analisis korelasi dan regresi, tujuannya untuk mengetahui apakah data yang kita miliki mempunyai hubungan yang linear atau tidak secara linear (berbanding lurus). Kriteria data yang mempunyai hubungan yang linear yaitu sig $<\mathbf{0 . 0 5} .^{24}$

ANOVA $^{\mathrm{b}}$

\begin{tabular}{|c|c|c|c|c|c|c|}
\hline \multicolumn{2}{|c|}{ Model } & $\begin{array}{l}\text { Sum of } \\
\text { Squares }\end{array}$ & $\mathrm{df}$ & Mean Square & $\mathrm{F}$ & Sig. \\
\hline \multirow[t]{3}{*}{1} & Regression & 2604.496 & 1 & 2604.496 & 40.840 & $.000^{a}$ \\
\hline & Residual & 2678.482 & 42 & 63.773 & & \\
\hline & Total & 5282.977 & 43 & & & \\
\hline
\end{tabular}

Dari hasil analisis salah satu variabel yang berhubungan di atas $\mathrm{X}$ dan $\mathrm{Y}$, dapat diketahui bahwa Sig dari linearity adalah 0.000 . Artinya nilai ini kurang dari 0.05 (0.000< 0.05). Dengan demikian dapat disimpulkan bahwa ada persamaan garis regresinya linear.

\footnotetext{
${ }^{24}$ Herson Anwar dan Lian G.Otaya, Statistika Pendidikan Teori dan Aplikasi, (Cet.I, Gorontalo: Sultan Amai Press, 2015) h.244
} 


\section{Uji korelasi}

Correlations
\begin{tabular}{|ll|r|r|}
\hline \multicolumn{1}{|c|}{} & \multicolumn{1}{c|}{$\mathrm{Y}$} & \multicolumn{1}{c|}{$\mathrm{X}$} \\
\hline Pearson & $\mathrm{Y}$ & 1.000 & .702 \\
Correlation & $\mathrm{X}$ & .702 & 1.000 \\
\hline Sig. (1-tailed) & $\mathrm{Y}$ &. & .000 \\
& $\mathrm{X}$ & .000 & \\
\hline $\mathrm{N}$ & $\mathrm{Y}$ & 44 & 44 \\
& $\mathrm{X}$ & 44 & 44 \\
\hline
\end{tabular}

Berdasarkan tabel Correlations di atas, bahwa besarnya hubungan antara variabel $\mathrm{X}$ (gaya kepemimpinan transformasional kepala sekolah) dengan variabel $\mathrm{Y}$ (prestasi peserta didik) yang dihitung dengan koefisien korelasi adalah 0.702 .

Berdasarkan hasil perhitungan tersebut menunjukkan adanya hubungan yang kuat antara gaya kepemimpinan transformasional kepala sekolah dengan prestasi peserta didik di SMA N 1 Pinolosian.

Pedoman Untuk Memberikan Interpretasi Koefesien Korelasi

\begin{tabular}{|c|c|}
\hline Interval Koefesien & Tingkat Hubungan \\
\hline $0,00-0,199$ & Sangat rendah \\
\hline $0,20-0,399$ & Rendah \\
\hline $0,40-0,599$ & Cukup Kuat \\
\hline $0,60-0,799$ & Kuat \\
\hline $0,80-1,000$ & Sangat kuat \\
\hline
\end{tabular}

\section{Uji regresi sederhana}

\begin{tabular}{|c|c|c|c|c|c|c|}
\hline & & & & oefficients ${ }^{a}$ & & \\
\hline & & $\begin{array}{r}\text { Unstanc } \\
\text { Coeffi }\end{array}$ & $\begin{array}{l}\text { rdized } \\
\text { ents }\end{array}$ & $\begin{array}{c}\text { Standardize } \\
d \\
\text { Coefficients }\end{array}$ & & \\
\hline & & B & $\begin{array}{l}\text { Std. } \\
\text { Error }\end{array}$ & Beta & $\mathrm{T}$ & Sig. \\
\hline 1 & $\begin{array}{l}\text { (Const } \\
\text { ant) }\end{array}$ & -4.401 & 19.038 & & -.231 & .818 \\
\hline & $X$ & 1.011 & .158 & .702 & 6.391 & .000 \\
\hline
\end{tabular}


Berdasarkan tabel Coefficient di atas dapat digambarkan bahwa persamaan regresi dalam penelitian ini, yakni sebagai berikut: $\mathrm{Y}=\mathrm{a}+\mathrm{b}_{\mathrm{x}}=-4.401+1.011 \mathrm{X}$.

Koefisien regresi sebesar 1.011 menyatakan bahwa setiap penambahan 1 (satu) nilai gaya kepemimpinan transformasional kepala sekolah akan memberikan peningkatan nilai prestasi peserta didik sebesar 1.011 .

ANOVA $^{\text {b }}$

\begin{tabular}{|ll|r|r|r|r|r|}
\hline \multicolumn{2}{|l|}{ Model } & \multicolumn{1}{|c|}{$\begin{array}{c}\text { Sum of } \\
\text { Squares }\end{array}$} & df & Mean Square & F & Sig. \\
\hline 1 & Regression & 2604.496 & 1 & 2604.496 & 40.840 & $.000^{\mathrm{a}}$ \\
& Residual & 2678.482 & 42 & 63.773 & & \\
& Total & 5282.977 & 43 & & & \\
\hline
\end{tabular}

Pada tabel ANOVA yang didapatkan melalui uji regresi sederhana dengan menggunakan SPSS 16.0 terdapat kolom untuk nilai $F$ dan ada kolom Sig. Jika kita menggunakan nilai $\mathrm{F}$ berarti kita juga harus mencari terlebih dahulu nilai $\mathrm{F}_{\text {tabel }}$ ya sehingga analisis ini akan lebih mudah menggunakan nilai Sig. Kriteria yang digunakan dalam pengujian ini ialah jika nilai Signifikansi Lebih dari atau sama dengan nilai alpha $(\alpha)$ yang telah ditentukan, maka $\mathrm{H}_{0}$ diterima yang artinya persamaan garis regresi tidak linear dan jika nilai Sig. kurang dari nilai alpha maka $\mathrm{H}_{0}$ ditolak yang artinya persamaan garis regresi linear.

Pada tabel ANOVA yang telah diperoleh dengan menggunakan SPSS 16.0 dapat dilihat nilai Signifikansi sebesar 0.000. Nilai Signifikansi ini kurang dari nilai $\alpha$ yaitu 0.05 artinya bahwa kita men0lak $\mathrm{H}_{0}$ berarti bahwa ada persamaan garis regresinya linear. Berdasarkan tabel ANOVA $^{\mathrm{b}}$ atau uji $\mathrm{F}$, ternyata didapat $\mathrm{F}_{\text {hitung }}$ adalah 40.840 . dengan tingkat signifikan $0.000^{\mathrm{a}}$. Karena probabilitas (0.000) jauh lebih kecil dari 0,05, sehingga model regresi dapat dipakai untuk memprediksi prestasi peserta didik (Variabel Y).Sedangkan untuk melihat seberapa besar kontribusis variabel independent yaitu variabel X (gaya kepemimpinan transformasional kepala sekolah) dapat diketahui dengan melihat nilai $R$-Square pada Tabel berikut:

\section{Model Summary}

\begin{tabular}{|l|r|r|r|r|}
\hline Model & $\mathrm{R}$ & $\mathrm{R}$ Square & $\begin{array}{c}\text { Adjusted R } \\
\text { Square }\end{array}$ & $\begin{array}{r}\text { Std. Error of } \\
\text { the Estimate }\end{array}$ \\
\hline 1 & $.702^{\mathrm{a}}$ & .493 & .481 & 7.986 \\
\hline
\end{tabular}

Pada tabel di atas dapat dilihat nilai $R$-Squarenya adalah 0.493 (nilai 0.493 yang berarti bahwa pengaruh variabel X (gaya kepemimpinan transformasional kepala sekolah) terhadap variabel Y (prestasi peserta didik) sebesar $49.3 \%$, pengaruh variabel lainnya adalah $50.7 \%$ yang merupakan pengaruh dari luar variabel gaya kepemimpinan transformasional kepala sekolah. 
7.Uji $\mathbf{j}_{\mathbf{t}}$

$\mathrm{Uji}_{\mathrm{t}}$ digunakan untuk menguji hipotesis yang telah ditetapkan sebelumya, uji hipotesis menjadi hal yang sangat penting dalam penelitian kuantitatif, sebab uji hipotesis akan memutuskan apakah asumsi yang kita buat berdasarkan parameter populasi dalam penelitian ini benar atau salah. Kepastian tentang benar dan salah terhadap asumsi yang dibuat, akan berpengaruh terhadap keputusan menerima atau menolak hipotesis berdasarkan pemaknaan terhadap sampel yang diambil dari populasi yang terdapat dalam penelitian ini. ${ }^{25}$

Adapun Uji t pada penelitan ini akan menguji signifikansi konstanta dan variabel dependen (gaya kepemimpinan transformasional kepala sekolah). Kriteria uji koefisien regresi dari variabel gaya kepemimpinan transformasional kepala sekolah (X) terhadap prestasi peserta didik $(\mathrm{Y})$ ialah sebagai berikut:

$\mathrm{H}_{\mathrm{a}}: \rho \neq 0 \quad$ : Terdapat pengaruh yang signifikan antara variabel gaya kepemimpinan transformasional kepala sekolah terhadap prestasi peserta didik

$\mathrm{H}_{0}: \rho=0 \quad$ : Tidak terdapat pengaruh yang signifikan antara variabel gaya kepemimpinan transformasional kepala sekolah terhadap prestasi peserta didik

Kaidah keputusan :

Jika nilai $t_{\text {hitung }}>t_{\text {tabel }}$, maka Ho ditolak dan Ha diterima, artinya koefisien regresi signifkan.

Jika nilai $t_{\text {hitung }}<\mathrm{t}_{\text {tabel }}$, maka Ho diterima dan Ha ditolak, artinya koefisien regresi tidak signifikan.

Berdasarkan tabel Coefficient di atas, pada kolom Unstandardized Coefficient, nilai $X$ (gaya kepemimpinan transformasional kepala sekolah) sebesar 1.011 dan nilai

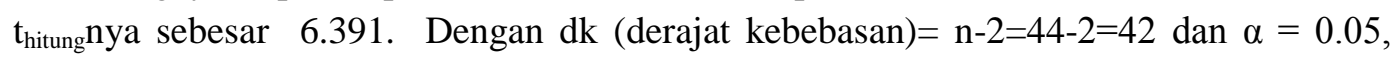
sehingga diperoleh nilai $t_{\text {tabel }}=0.297$. Sehingga nilai $t_{\text {hitung }}>t_{\text {tabel }}$ atau $6.391>0.297$, maka $\mathrm{H}_{0}$ ditolak dan Ha diterima, yang berarti koefisen regresi berpengaruh secara signifikan. Dengan demikian terbukti berdasarkan Uji t bahwa gaya kepemimpinan transformasional kepala sekolah $(\mathrm{X})$ berpengaruh secara signifikan terhadap prestasi peserta didik (Y) di Sekolah Menegah Atas Negeri 1 Pinolosian.

\section{PEMBAHASAN}

Gaya kepemimpinan merupakan norma perilaku yang di gunakan oleh seseorang pada saat orang tersebut mencoba mempengaruhi perilaku orang lain. Gaya kepemimpinan adalah suatu pola perilaku yang konsisten yang di tunjukkan oleh pemimpin dan di ketahui pihak lain. Ketika pemimpin berusaha mempengaruhi kegiatankegiatan orang lain. Gaya kepemimpinan juga merupakan pola tingkah laku seorang pemimpin dalam proses mengarahkan dan mempengaruhi guru dan siswa.

Penelitian ini merupakan penelitian kuantitatif dengan tujuan untuk mengetahui seberapa besar pengaruh gaya kepemimpinan transformasional kepala sekolah terhadap

\footnotetext{
${ }^{25}$ Boediono, Wayan Koster, Teori dan Aplikasi Statistika dan Probalitas: Sederhana, Lugas, dan Mudah Dimengerti,(Cet.IV, Bandung: PT.Remaja Rosda Karya, 2008) h.434.
} 
prestasi peserta didik di SMA N 1 Pinolosian. Penelitian ini dilaksanakan di SMA N 1 Pinolosian.

Adapun dalam pengumpulan data, peneliti menggunakan angket (kuesioner). Sebelum melakukan penelitian peneliti mengujicobakan angket yang akan di gunakan di sekolah MA Muhammadiyah Kota Gorontalo. Setelah melakukan uji coba instrumen variabel $\mathrm{X}$ dan $\mathrm{Y}$ terdapat beberapa item soal yang tidak Valid, maka yang tidak valid tersebut di hilangkan dan item soal yang valid di gunakan untuk pengumpulan data. Angket tersebut berjumlah 55 pernyataan yang terbagi dalam dua variabel, 27 pernyataan pada variabel gaya kepemimpinan transformasional kepala sekolah dan 28 pernyataan pada variabel prestasi peserta didik di sebarkan kepada sampel penelitian yang berjumlah 20 orang guru dan 75 peserta didik sebagai responden.

Setelah angket di sebarkan, selanjutnya adalah uji validitas dan reliablitas. Setelah dilakukan uji validitas dan reliabilitas maka untuk mengetahui variabel (X) gaya kepemimpinan transformasional kepala sekolah, dalam angket tersebut terdiri dari 5 sub variabel.Untuk variabel (Y) prestasi peserta didik, terdiri dari 2 sub variabel.

Adapun dalam peneltian ini, Hubungan antara variabel $\mathrm{X}$ (gaya kepemimpinan transformasional kepala sekolah) dan variabel Y (prestasi peserta didik) di Sekolah Menengah Atas Negeri 1 Pinolosian memiliki nilai koefisien korelasi sebesar 0.493 atau setara dengan $49.3 \%$. capaian nilai koefisein korelasi antara variabel $\mathrm{X}$ dan variabel $\mathrm{Y}$ dalam penelitian ini masuk dalam kategori hubungan yang kuat antara gaya kepemimpinan transformasional kepala sekolah dengan prestasi peserta didik di Sekolah Menengah Atas Negeri 1 Pinolosian.

Hasil koefisien korelasi dalam penelitian ini juga menunjukkan bahwa hubungan antara variabel $\mathrm{X}$ (gaya kepemimpinan transformasional kepala sekolah) dan variabel $\mathrm{Y}$ (prestasi peserta didik) dalam kategori hubungan koresi yang positif. Korelasi posistif berarti semakin tinggi hubungan gaya kepemimpinan transformasional kepala sekolah maka akan berdampak pada semakin tinggi pula prestasi peserta didik.

Setelah diketahui bahwa terdapat hubungan antara variabel $\mathrm{X}$ (Gaya kepemimpinan transformasional kepala sekolah di SMA N 1 PINOLOSIAN sebesar 0.493. Maka nilai koefisien korelasi tersebut, dapat menjadi acuan untuk mengajukan penelitian ini dalam pengujian regresi sederhana untuk mendapatkan nilai konstanta variabel $\mathrm{X}$ (gaya kepemimpinan transformasional kepala sekolah) dan sekaligus mendapatkan nilai persamaan regresi yang bertujuan untuk meramalkan perubahan nilai variabel Y (prestasi peserta didik) di SMA N 1 Pinolosian yang disebabkan oleh variabel $\mathrm{X}$ (gaya kepemimpinan transformasional kepala sekolah).

Melalui uji regresi sederhana yang dilakukan mengunakan proram SPSS 16.0 di dapatkan hasil persamaan regresi, sebagai berikut :

$\mathbf{Y}=\mathbf{a}+\mathbf{b} \mathbf{x}$

$\mathbf{Y}=-4.401+1.011(\mathbf{x})$

Berdasarkan persamaan tersebut dapat di deskripsikan bahwa konstanta sebesar 4.401 menyatakan jika tidak ada kenaikan nilai dari variabel $\mathrm{X}$ (gaya kepemimpinan transformasional kepala sekolah) maka nilai variabel Y (prestasi peserta didik) adalah 4.401. Koefisien regresi sebesar 1.011 menyatakan bahwa setiap penambahan 1 (satu) 
nilai gaya kepemimpinan transformasional kepala sekolah akan memberikan peningkatan nilai prestasi peserta didik sebesar 1.011 .

Dengan persamaan regresi tersebut diatas, maka nilai variabel Y (prestasi peserta didik) dapat diramalkan jika nilai variabel $\mathrm{X}$ (gaya kepemimpinan transformasional kepala sekolah) diketahui. Hal ini dapat dicontohkan misalnya: jika nilai variabel $\mathrm{X}=106$ yang diambil dari nilai terkecil pada nilai total penelitian ini berdasarkan hasil tabulasi data variabel X (gaya kepemimpinan transformasional kepala sekolah) maka diramalkan nilai variabel Y (prestasi peserta didik) ialah sebagai berikut:

$\mathbf{Y}=\mathbf{a}+\mathbf{b} \mathbf{x}$

$Y=-4.401+1.011(x)$

$Y=-4.401+1.011(106)$

$Y=-4.401+107.166$

$\mathrm{Y}=\mathbf{1 0 2 . 7 6 5}$

Berdasarkan peramalan yang dilakukan melalui persamaan regresi diatas dengan nilai variabel $X$ (gaya kepemimpinana transformasional kepala sekolah) $=106$, maka nilai variabel Y (prestasi peserta didik) sebesar 102.765. Sebagai suatu ramalan, persamaan regresi tidak memberikan jawaban yang pasti tentang apa yang akan terjadi, melainkan berusaha mencari pendekatan terhadap apa yang akan terjadi sehingga dapat mengantisipasi asumsi probalitas kesalahan pengambilan keputusan terhadap kasus tertentu. ${ }^{26}$

Persamaan regresi sederhana diatas menunjukkan bahwa jika nilai variabel $\mathrm{X}$ sebesar 106, maka nilai Y di prediksikan sebesar 102.765 . Dengan adanya prediksi yang diperoleh melalui persaman 102.765 regresi, akan sangat membantu pengambilan keputusan berdasarkan data informasi yang tersedia, atau dengan kata lain, pengunaan persamaan regresi ini, akan dapat membantu memprediksikan hasil yang di dapatkan dimasa yang akan datang berdasarkan keputusan yang dibuat saat ini.

Adapun kontribusi pengaruh variabel $\mathrm{X}$ (gaya kepemimpinan transformasional kepala sekolah) terhadap variabel Y (prestasi peserta didik) di Sekolah Menengah Atas Negeri 1 Pinolosian berdasarkan tabel model sumary pada nilai R.Square didapatkan kontribusi variabel $\mathrm{X}$ terhadap variabel $\mathrm{Y}$, sebesar 0.493 atau setara dengan $49.3 \%$.

Berdasarkan nilai ini pula maka dapat diketahui bahwa, variabel $\mathrm{X}$ (gaya kepemimpinan transformasional kepala sekolah) memberikan sumbangan pengaruh sebesar $49.3 \%$ yang berarti terdapat $50.7 \%$ faktor lain yang turut mempengaruh variabel Y (prestasi peserta didik) selain gaya kepemimpinan transformasional kepala sekolah.

Dengan besaran koefiseien korelasi sebesar 0.702 dan kontribusi pengaruh nilai variabel X ke Y sebesar 0.493. Maka dipandang perlu untuk melakukan uji hipotesis, melalui Uji t yang bertujuan untuk melihat signifikansi pengaruh variabel $\mathrm{X}$ terhadap variabel $\mathrm{Y}$, dan sekaligus melakukan uji pengambilan keputusan apakah akan memerima ataukah menolak hipotesis.

${ }^{26}$ Riduwan, Sunarto, Pengantar Statistika Untuk Penelitian: Pendidikan, Sosial, Ekonomi, dan Bisnis, (Cet II, Bandung: Alfabeta, 2009), h.96. 
Berdasarkan uji hipotesis yang dilakukan dengan perbandingan $\mathrm{T}_{\text {hitung }}>\mathrm{T}_{\text {tabel }}=$ $6.391>0.297$, maka dapat disimpulkan bahwa Ho ditolak dan Ha diterima, yang berarti bahwa gaya kepemimpinan transformasional kepala sekolah berpengaruh secara signifikan terhadap prestasi peserta didik di Sekolah Menengah Atas Negeri 1 Pinolosian, dengan sumbangan pengaruh sebesar $49.3 \%$ dan koefisien korelasi sebesar $70.2 \%$.

Merujuk pada hasil akhir dalam penelitian, terlihat bahwa pengaruh variabel $\mathrm{X}$ (gaya kepemimpinan transformasional kepala sekolah) terhadap variabel Y (prestasi peserta didik) di Sekolah Menengah Atas Negeri 1 pinolosian sebesar 49.3\%. Dengan ditemukan besaran pengaruh variabel $\mathrm{X}$ terhadap $\mathrm{Y}$ akan memperlihatkan adanya faktor lain sejumlah $50.7 \%$ yang tidak diteliti dalam penelitian ini yang juga turut mempengaruhi variabel Y (prestasi peserta didik) di Sekolah Menengah Atas Negeri 1 Pinolosian.

Besaran pengaruh sebesar $50.7 \%$ yang disumbangkan oleh faktor lain terhadap nilai variabel Y (Prestasi peserta didik) merupakan temuan empirik yang mengambarkan perlunya penelitian lanjutan yang lebih mendalam lagi untuk dapat mengidenifikasi faktor-faktor lain di luar pengaruh gaya kepemimpinan transformasional kepala sekolah yang menyebabkan suatu prestasi peserta didik dapat meningkat, khususnya di SMA N 1 Pinolosian. Hal ini menjadi sesuatu yang dipandang penting sebab penelitian ini hanya terkonsentarasi pengaruh gaya kepemimpinan transformasional kepala sekolah terhadap prestasi peserta didik.

Dengan ditemukannya $49.3 \%$ pengaruh gaya kepemimpinan transformasional kepala sekolah, maka akan menunjukkan angka $50.7 \%$ faktor lain yang turut mempengaruhi prestasi peserta didik yang tidak diteliti dalam penelitian ini.

Hasil analisis penelitian ini, berdasarkan observasi awal yang lakukan di SMA N 1 Pinolosian, telah mengidentifikasi beberapa faktor-faktor penting selain gaya kepemimpinan transformasional kepala sekolah, yang turut mempengaruhi prestasi peserta didik yaitu, peran guru-guru,kesadaran dari diri peserta didik dan lain-lain.

Ada beberapa faktor yang ditemukan dalam observasi penelitian menunjukkan bahwa penelitian lanjutan sangat penting untuk dilakukan dalam rangka membuat pemetaan secara komprehensif dari faktor-faktor yang berpengaruh terhadap prestasi peserta didik di SMA N 1 Pinolosian.

Penelitian ini telah membuktikan bahwa gaya kepemimpinan transformasional kepala sekolah memiliki sumbangan pengaruh sebesar $49.3 \%$ dengan tingkat korelasi sebesar $70.2 \%$, dan melalui $\left(\mathrm{Uji}_{\mathrm{t}}\right.$ ) terbukti bahwa gaya kepemimpinan transformasional kepala sekolah berpengaruh secara signifikan terhadap prestasi peserta didik di SMA N 1 Pinolosian dengan perbandingan $\mathrm{T}_{\text {hitung }}>\mathrm{T}_{\text {tabel }}=6.391>0.297$.

\section{KESIMPULAN}

Berdasarkan hasil penelitian yang telah dibahas pada bab sebelumnya dan untuk menjawab rumusan masalah pada penelitian ini, maka akhir dari skripsi dapat di tarik kesimpulan sebagai berikut:

1. Berdasarkan uji hipotesis melalui Uji terbukti bahwa variabel $\mathrm{X}$ (gaya kepemimpinan transformasional kepala sekolah) berpengaruh secara signifikan terhadap variabel $\mathrm{Y}$ (prestasi peserta didik) di SMA N 1 Pinolosian, dengan perbandingan $\mathrm{T}_{\text {hitung }}>\mathrm{T}_{\text {tabel }}=6.391>0.297$ 
2. Melalui analisis regresi sederhana pada tabel R Square, diketahui Pengaruh variabel $\mathrm{X}$ (gaya kepemimpinan transformasional kepala sekolah) terhadap variabel $\mathrm{Y}$ (prestasi peserta didik) di SMA N 1 Pinolosian sebesar $49.3 \%$ yang berarti terdapat $50.7 \%$ prestasi peserta didik dipengaruhi oleh faktor yang lain.

\section{DAFTAR PUSTAKA}

Anwar Herson, Lian G. Otaya, Pedoman Penulisan Karya Ilmiah, Gorontalo: Sultan Amai Press, 2014.

Arikunto Suharsimi, Prosedur Penelitian Suatu Pendekatan Praktik, Jakarta: PT Rineka Cipta, 2010.

\footnotetext{
- Prosedur Penelitian Suatu Pendekatan Praktik. Edisi Revisi ke VI. Jakarta: Rineka Cipta, 2006.

- Prosedur Penelitian, Jakarta: Renika Cipta, 2001.
}

Basri Hasan \& Tatang, Kepemimpinan Pendidikan, Bandung : Pustaka Setia,2015

Danim Sudarwan \& Suparno,Manajemen dan Kepemimpinan Transformasional Kepala Sekolahan,Jakarta : PT Rineka Cipta,2009

,Perkembangan Peserta Didik, Bandung :Alvabeta,2017.

Emzir, Metodologi Penelitian Pendidikan Kuantitatif \& Kualitatif, Jakarta: Rajawali pres, 2010.

Fahmi Irham, Manajemen Kepemimpinan Teori \& Aplikasi, Bandung : Alfabeta, 2017.

Ghony M. Junaidi dan almanshur fauzan, Metodologi Penelitian Pendidikan Pendekatan

Kuantitatif, Malang: UIN-Malang Press, 2009.

Karwati Euis \& Priansa Juni Donni, Manajemen Kelas,Bandung : Alfabeta,2015

Noor Juliansyah ,Metodologi Penelitian,Kencana,Jakarta 2012.

Priansa, manajemen supervisi dan kepemimpinan kepala sekolah,Bandung : alfabeta , 2014.

Purwanto, Metodologi Penelitian Kuantitatif Untuk Psikologi dan Pendidikan, Yogyakarta: Pustaka Pelajar, 2010.

Raihani , kepemimpinan sekolah transformatif, yogyakarta : LKIS, 2010.

Rivai Veithzal, Kepemimpinan dan Perilaku Organisasi,Ed. 2, Jakarta : PT Raja Grafindo Persada, 2006.

Sidik, Firman. "KONSEP PENGEMBANGAN KURIKULUM PENDIDIKAN ISLAM." (2016): 100-114.

Sugiono, Metode Penelitian Kombinas, Cet. 5; Bandung: Alfabeta, 2014.

, Metode Penelitian Kuantitatif, Kualitatif dan $R \& D$, Bandung : cv. Alfabeta, 2015.

_, Metode Penelitian Manajemen, Cet. I, Bandung: Alfabeta, 2013.

- metode penelitian,bandung : alfabeta,2015.

Suranto, Metodologi Penelitian dalam Pendidikan dengan Program SPSS, Semarang: CV. Ghiyyas Putra, 2009.

Umiarso \& Wahab Abd, Kepemimpinan Pendidikan dan Kecerdasan Spiritual, Jogjakarta: Ar-Ruzz Media,2016.

Undang-Undang Negara Republik Indonesia, Nomor 20 tahun 2003 tentang Sistem Pendidikan Nasional. 
Wibowo Agus ,Manager \& Leader Sekolah Masa Depan, Yogyakarta : Pustaka Pelajar, 2014.

Winarsunu Tulus, Statistik Dalam Penelitian Psikologi dan Pendidikan, Malang: UMM Press, 2006.

Zuhriah Nurul, Metodologi Penelian Sosial dan Pendidikan Teori-Aplikasi, Jakarta: Bumi Aksara, 2009. 